POST-CONTEMPORARY INTERVENTIONS

Series Editors: Stanley Fish and Fredric Jameson 


\section{QUESTIONS OF IRAVEL}

Postmodern Discourses of Displacement

\section{Caren Maplan}


Third printing, 2000

(C) I996 Duke University Press

All rights reserved

Printed in the United States of America on acid-free paper $\infty$ Typeset in Monotype Garamond by Tseng Information Systems, Inc. Library of Congress Cataloging-in-Publication Data appear on the last printed page of this book. 
For Eric 
